\title{
TAF12 wt Allele
}

National Cancer Institute

\section{Source}

National Cancer Institute. TAF12 wt Allele. NCI Thesaurus. Code C52599.

Human TAF12 wild-type allele is located in the vicinity of 1 p35.3 and is approximately 40

$\mathrm{kb}$ in length. This allele, which encodes transcription initiation factor TFIID subunit 12

protein, is involved in the regulation of RNA polymerase II-mediated transcription. 